\title{
ADRENAL SECRETION PRODUCED BY ASPHYXIA
}

\author{
B. A. HOUSSAY AND E. A. MOLINELLI \\ From the Institute of Physiology, Faculty of Medicine, Buenos Aires \\ Received for publication January 18, 1926
}

Asphyxia produces a marked epinephrin discharge. This fact reported by several authors has been denied by others. Our present observations confirm the existence and give some insight into the cause of this phenomenon.

Review of Literature. Several methods have been used to study adrenal secretion during asphyxia.

Chromaphil reaction and epinephrin content. Asphyxia produced by closing the trachea or breathing carbon monoxide (illuminating gas) diminishes the intensity of the chromaphil reaction and the epinephrin content of the adrenals in dogs, rabbits, cocks and monkeys (Kahn, 1912; Borberg, 1913). The results were obtained by comparing one adrenal taken out before asphyxia with the other taken out after asphyxia.

Kodama, working with cats and dogs asphyxiated by closing the trachea, found a smaller epinephrin content in the adrenals than is usually found in normal animals.

Direct estimation of adrenal secretion. Some investigators have simply measured the epinephrin concentration of adrenal blood. Cannon and Hoskins (1911) introduced a catheter through the femoral vein into the vena cava up to the level of the lumbo-adrenal veins. Blood so obtained after asphyxia inhibited the contractions of the isolated intestine of rabbits, while blood from the femoral vein remained inactive. This effect is due to adrenal secretion as it is not observed once the adrenals have been taken out, unless asphyxia is extreme.

Czubalski (1913) also found that the defibrinated blood of dogs drawn after asphyxia inhibits the contractions and relaxes the isolated intestine.

Gley and Quinquaud (1917) measuring the blood-pressure-raising effect reported an increase of two to three times the epinephrin concentration of adrenal blood in asphyxiated dogs, but attach no importance to this fact as a cause of the rise in blood pressure produced by asphyxia.

Volhard and Hülse (1923) studied three curarized dogs and could not find epinephrin in citrated blood (Trendelenburg's surviving-frog method) taken from the femoral vein or the heart, even after asphyxia. Curarization and the use of blood from the general circulation suffice to explain these negative results. 
Stewart and Rogoff have very justly criticized all these experiments on the ground that only epinephrin concentration was measured and no account taken of the total output. Simple modifications of circulatory conditions may produce great variations in the epinephrin concentration. To ascertain a true increase in adrenal secretion it is necessary to measure the amount of epinephrin secreted per minute. This they have done and Kodama has repeated their experiments. Stewart and Rogoff's numerous papers were published between 1916 and 1920. They used anesthetized and decerebrated (1917) cats and dogs. The epinephrin output was estimated in blood collected in a "cava pocket" and the effect of this blood was tested on a rabbit's isolated intestine and uterus (1917). They found no increased epinephrin output during or after asphyxia. These results they confirmed by the use of the denervated iris (1916) and blood-pressure curves (1916) which served as internal tests in the asphyxiated animals.

Kodama (1924) followed the same technique as Stewart and Rogoff but his results were absolutely contradictory to those obtained by them. In 11 cats and 6 dogs he found that asphyxia produced an increased epinephrin discharge. At the end of the experiment the epinephrin content of the adrenals was estimated and found to be slightly smaller than that of normal dogs; in cats no such alteration was demonstrated.

Blood pressure as an internal test. Anrep (1912) observed that asphyxia produced a smaller rise in blood pressure when the adrenals were excluded from the circulation.

Czubalski (1913) reported that asphyxia causes a rise of blood pressure in 3 to 4 minutes even after section of the medulla, spinal cord, splanchnic nerves and vagi. Sometimes this rise was considerable, in one case from 34 to $100 \mathrm{~mm}$. Hg. Adrenalectomy suppresses the increase of blood pressure. He supposed that the excess $\mathrm{CO}_{2}$ prevented the normal destruction of epinephrin secreted into the blood stream and allowed it to accumulate until a sufficient quantity was present to produce effects observed.

Stewart and Rogoff (1916) collected adrenal blood in a "cava pocket" during a given time and measured the blood-pressure-raising effect in the same animal before and after asphyxia (closure of the trachea) observing identical increases in both cases.

Gley and Quinquaud (1917-18-21-23) maintain that the rise of blood pressure produced by asphyxia depends on the integrity of the central nervous system. Adrenalectomy, or ligature of the adrenal veins, section of both major splanchnics, evisceration (removal of stomach, intestine, pancreas, liver, spleen and kidneys) do not modify asphyxial vasoconstriction. In some cases a less marked increase was observed after tying the adrenals but this fact was not considered proof of an epinephrin effect. Asphyxial vasoconstriction was seen in the blood vessels of the lungs, abdominal viscera and musculo-cutaneous structures. 
Denervated limb. Anrep (1912) showed that during asphyxia (80 seconds after commencement in the record published) produced by closing the trachea, there is a constriction of the denervated limb (dog, apparently) without any previous dilatation. If the adrenals have been tied off, or the splanchnics cut, no constriction is present.

Itami (1912) also observed constriction of the denervated limbs of dogs breathing 10 to 12 per cent mixtures of $\mathrm{CO}_{2}$. The volume of the limbs followed the blood-pressure changes passively when the spinal cord was destroyed from the second cervical segment downwards. He suspected an adrenal factor in asphyxial vasoconstriction.

Pearlman and Vincent (1919) were not able to confirm these results. This might be owing to the fact that they used ether, curare and morphia as anesthetics and so diminished the reactions of the adrenals and the denervated limbs. As will be seen later, we have obtained results similar to those reported by Anrep.

Suprareno-jugular anastomosis. In 1923 Tournade and Chabrol described a method of studying adrenal secretion consisting in the anastomosis of the lumbo-adrenal vein of one dog (donor) with the jugular vein of another (recipient) so that all blood leaving the first animal's adrenal was emptied into the circulation of the receptor. The donor's remaining adrenal was taken out. Asphyxia in the donor produced a rise in blood pressure and a slowing of the heart beat in both animals due to a nervous mechanism in the donor and to a humoral influence in the recipient. Section of the major and minor splanchnic nerves suppresses these results. When only the major splanchnics are severed an adrenal discharge may, in some cases, be observed.

In other experiments the kidney of one $\operatorname{dog} \mathrm{A}$, was supplied with blood by a second $\operatorname{dog}$, B. Asphyxia in A produced constriction of its own kidney through the vasomotor nerves that had been left intact. Asphyxia in $\mathrm{B}$ also produced constriction of A's kidney through an adrenal discharge, no constriction being present when $\mathrm{B}$ had been previously adrenalectomized.

The denervated iris as an internal test. Budge in 1855 and later Anderson (1903) described a dilatation of the denervated iris during asphyxia, the so-called "paradoxical reaction." Elliot (1912) ascribed this phenomenon to an adrenal influence. Moderate asphyxia produced a dilatation of the iris denervated by extirpation of the superior cervical ganglion. After adrenalectomy no dilatation was observed unless asphyxia was extreme.

Kellaway (1915) confirmed these results and found that it was sufficient to sever both splanchnics to prevent pupillary dilatation during moderate asphyxia.

Stewart and Rogoff (1916) did not confirm these conclusions with their "cava-pocket" method. Adrenal blood was collected during a given time 
and then thrown into the circulation; the denervated iris dilated to the same extent before and after asphyxia. Cats with adrenal secretion suppressed (by extirpation of one and denervation of the other adrenal) showed a dilatation of the iris equal to that of normal animals (1916). Later (1920) they observed that Kellaway's experiments were not valid as proof of an increased adrenal secretion, an accelerated circulation might have brought in a given time a larger quantity of epinephrin to the denervated iris without the existence of a true increase in secretion.

Dilatation of the denervated iris is due, according to Kellaway (1919), to an adrenal discharge produced by a diminished oxygen supply; the effective decrease being 7 to 9 per cent, while the accumulation of $\mathrm{CO}_{2}$ will give no result even when it reaches a concentration of 15 per cent. Section of the splanchnics, adrenalectomy or both operations done simultaneously suppresses the dilatation. Extreme asphyxia produces a certain degree of dilatation that may be explained by an epinephrin discharge of the accessory chromaphil tissue. It is also possible to prevent the appearance of such a dilatation by destroying the adrenal medulla by means of tubes of radium emanation placed within the gland.

IIartman and Hartman (1923) obtained dilatation of the denervated iris after 40 seconds of asphyxia in cats with only one adrenal, although the remaining gland had its medulla destroyed by cauterization. This result was explained by attributing to the cortex the capacity to secrete epinephrin. Hartman, McCordock and Loder (1923) observed a prolonged dilatation of the denervated iris if the preparation had been made by extirpating both the superior cervical ganglion and the ciliary ganglion. In this condition the pupil remained dilated 4 minutes after asphyxia, and in some cases as long as 30 minutes. The dilatation disappears if the adrenal veins are tied, and reappears once the circulation is restored.

The denervated heart as an internal test. The increase in heart rate produced by slight asphyxia is suppressed when the adrenal veins are ligatured in an unanesthetized dog (Gasser and Meek, 1914). Asphyxia accelerates the rate of the denervated heart owing to an increased adrenal secretion (Cannon, 1919). Stewart and Rogoff (1920) deny all importance to the adrenal discharge in this case, arguing that the smaller increases in heart rate can be observed without any alterations in the adrenal secretion, owing to low blood pressure produced by the trauma of the experiment.

Cannon and Carrasco-Formiguera (1922) confirmed Cannon's previous work. Asphyxia during 45 seconds increases the heart rate in a cat with denervated heart and liver. When the adrenal blood does not enter the circulation (closure of the vena cava) asphyxia does not produce an increase in heart rate, but does so again if the adrenal circulation is restored.

Searles (1923) observed in fasting dogs an increase in rate of the denervated heart after asphyxia, which did not occur if the lumbo-adrenal veins were tied and reappeared once the ligatures were removed. 
Hyperglycemia as an internal test. Starkenstein (1912) maintained that hyperglycemia produced by asphyxia does not occur in the adrenalectomized rabbit. Stewart and Rogoff (1917-18-20) deny any adrenal factor in this increase of blood sugar. Asphyxia produces the same degree of hyperglycemia in cats with one adrenal extirpated and the other denervated as it does in normal animals (1917). Adrenalectomized animals have a normal hyperglycemia after asphyxia if time is given them to recover from the operation (1918). Kellaway (1919) observed hyperglycemia in adrenalectomized cats after asphyxia. He concludes that other factors besides the adrenals influence the blood sugar, but remarks that quantities of epinephrin too small to cause pupillary dilatation produce a definite increase of the blood sugar. Anoxemia is the primary cause of these results.

Brain temperature. Asphyxia is accompanied by an increase of temperature in the brain due to adrenal discharge as it is not observed once the adrenals have been taken out. (Crile, Rowland and Wallace, 1923.)

Original EXPERIMENTs. A marked adrenal discharge is produced by asphyxia. We have observed it in the following circumstances: 1, closure of the trachea; 2 , injection of curare or cobra venom; 3 , potassium cyanide administration, and 4, breathing of several gas mixtures.

A. Closure of the trachea: All experiments were performed on dogs anesthetized with chloralose $(0.10$ gram per kgm., intravenously injected), with both vagi cut and under artificial respiration. As tests we used the denervated limb and the suprareno-jugular anastomosis. In some cases quantitative estimations were made.

The denervated limb as internal test: Two experiments performed confirmed Anrep's previous work. Blood-pressure and hind-leg-volume curves (Dale and Richard's plethysmograph) were taken. The trachea was closed by means of a hemostat for 4 and 6 minutes. Ninety seconds and 150 seconds after the commencement of asphyxia an intense constriction of the leg was recorded lasting 3 and 5 minutes. The adrenals were taken out in one animal and both major and minor splanchnics severed in the other. A new period of asphyxia lasting 5 minutes did not produce constriction of the leg and the increase in blood pressure was not as great as in the first case.

Suprareno-jugular anastomosis: This excellent method of Tournade and Chabrol is free from all criticism as a medium to study asphyxial adrenal secretion. The central end of the left lumbo-adrenal vein of a dog (donor) was ligatured, the peripheral end was united to the jugular vein of a second dog (recipient) by means of a venous segment. All the adrenal blood from the left gland of the first dog passes into the circulation of the second, 
whose weight was about 50 per cent less. The recipient's heart was denervated. Both animals were under artificial respiration.

In four experiments the donor's trachea was closed from 4 to 6 minutes. Two to five minutes after the start an intense adrenal discharge was registered by a marked rise in blood pressure and increased heart rate in the recipient. The blood pressure rose sharply in the donor before it did so in the recipient and remained high for $3 \frac{1}{2}$ to 6 minutes. The heart rate increased and remained rapid during this same lapse of time but gradually came down to the previous rate.

In one case when the respiration was reëstablished a rise in blood pressure was observed in both dogs.

TABLE 1

\begin{tabular}{|c|c|c|c|c|c|c|c|c|c|c|}
\hline \multirow{2}{*}{ DATE } & \multicolumn{2}{|c|}{ WEXGHT } & \multirow{2}{*}{ 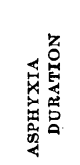 } & \multirow{2}{*}{ 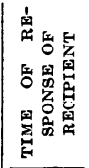 } & \multicolumn{2}{|c|}{$\begin{array}{c}\text { BLOOD } \\
\text { PRESSURE RISE }\end{array}$} & \multicolumn{2}{|c|}{$\begin{array}{c}\text { BLOOD } \\
\text { PRESSURE RISE } \\
\text { DURATION }\end{array}$} & \multirow{2}{*}{ 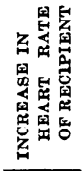 } & \multirow{2}{*}{ 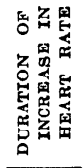 } \\
\hline & Donor & $\begin{array}{c}\text { Recip- } \\
\text { ient }\end{array}$ & & & Donor & $\begin{array}{c}\text { Recip- } \\
\text { ient }\end{array}$ & Donor & $\begin{array}{c}\text { Recip- } \\
\text { ient }\end{array}$ & & \\
\hline & $\mathrm{kgm}$. & $\mathrm{kgm}$. & minutes & minutes & $m m . H g$ & $m m . H g$ & minutes & minutes & & minutes \\
\hline อ $18 / 1925$ & 18 & 8 & 6 & 5 & 114 & 264 & 9 & $4 \frac{1}{2}$ & 90 & 4 \\
\hline $5 / 20 / 1925$ & 17 & 9.5 & 5 & 4 & 44 & 84 & & 7 & 24 & 5 \\
\hline $5_{/} 22 / 1925$ & 18 & 9 & 4 & 2 & 110 & 90 & 7 & 6 & 26 & 6 \\
\hline $\bar{\delta} / 26 / 1925$ & 15 & 10 & 4 & $2 \frac{1}{4}$ & 100 & 160 & $8 \frac{1}{2}$ & 5 & 52 & $3 \frac{1}{2}$ \\
\hline
\end{tabular}

Quantitative measurements of adrenal discharge: The adrenal discharge produced by asphyxia is a large one and lasts longer than that produced by stimulating the splanchnics or the bulb. In some cases the secretion amounts to $0.05 \mathrm{mgm}$. or more per minute. This quantity is sufficient to produce hyperglycemia, inhibit intestinal movements and diminish the volume of the kidney or the spleen.

Three experiments were performed to measure the amount of epinephrin secreted. The adrenal blood of the donor was collected every minute or every two minutes in tubes with $0.05 \mathrm{gm}$. of sodium citrate in $1 \mathrm{cc}$. normal saline. This blood was injected as quickly as possible into the jugular vein of dogs (two animals used in each experiment) whose blood pressure and heart rate were then recorded. At the beginning and end of the experiment tests were made with adrenalin which had been previously titrated by the Cannon, Folin and Denis method, and the increase in blood pressure and heart rate measured.

1st experiment. Donor's weight $20.5 \mathrm{kgm}$.; the left adrenal weighed 1.52 grams. Asphyxia was produced by closing the trachea for six minutes. The adrenal blood 
was tested as described above on two dogs weighing 7 and $8.5 \mathrm{kgm}$. The following results were obtained:

\begin{tabular}{|c|c|c|}
\hline & $\begin{array}{c}\text { BLOOD } \\
\text { COLLECTED }\end{array}$ & $\begin{array}{l}\text { EPINEPHRIN } \\
\text { CONTENT }\end{array}$ \\
\hline & $c c$. & mgm. \\
\hline 1 minute before asphyxia. $\ldots \ldots \ldots \ldots \ldots \ldots \ldots$ & 7.2 & $<0.001$ \\
\hline Asphyxia: Duration in minutes: & & \\
\hline 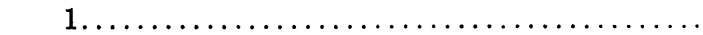 & 6.0 & $<0.001$ \\
\hline $2 \ldots \ldots \ldots \ldots \ldots \ldots \ldots \ldots \ldots$ & 14.0 & $<0.001$ \\
\hline 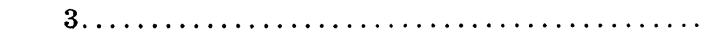 & 13.0 & 0.005 \\
\hline $4 \ldots \ldots \ldots \ldots \ldots \ldots \ldots \ldots \ldots \ldots \ldots \ldots \ldots$ & 12.0 & 0.025 \\
\hline $5 \ldots \ldots$ & 7.0 & 0.045 \\
\hline $6 \ldots \ldots \ldots \ldots \ldots$ & 7.5 & 0.030 \\
\hline $7 \ldots \ldots \ldots$ & 6.0 & 0.020 \\
\hline $8 \ldots \ldots \ldots \ldots$ & 3.0 & 0.002 \\
\hline
\end{tabular}

2nd experiment. Donor's weight $16 \mathrm{kgm}$.; left adrenal 1.20 grams. Test dogs weighed $9 \mathrm{kgm}$. each. Asphyxia by closing trachea lasted six minutes.

\begin{tabular}{|c|c|c|}
\hline & $\begin{array}{c}\text { BLOOD } \\
\text { COLLECTED }\end{array}$ & $\begin{array}{l}\text { BPTNEPHRTN } \\
\text { CONTENT }\end{array}$ \\
\hline & $c c$. & mgm. \\
\hline 2 minutes before asphyxia $\ldots \ldots \ldots \ldots \ldots \ldots$ & 4 & traces \\
\hline Asphyxia: Duration in minutes: & & \\
\hline $1-2 \ldots \ldots \ldots \ldots \ldots \ldots \ldots \ldots \ldots \ldots \ldots \ldots$ & 4 & 0.003 \\
\hline $3-4 \ldots \ldots \ldots \ldots \ldots \ldots \ldots \ldots \ldots \ldots \ldots$ & 10 & 0.004 \\
\hline $5-6 \ldots \ldots \ldots \ldots \ldots \ldots \ldots \ldots \ldots \ldots$ & 6 & 0.020 \\
\hline
\end{tabular}

Fig. 1. 5/26/1925. Blood pressure of recipient (10 kgm.) upper curve. Blood pressure of donor $(15 \mathrm{kgm}$.) lower curve. Between 1 and 2 donor's trachea closed.

Fig. 2. 5/22/1925. Upper curve-Blood pressure of recipient. Lower curveBlood pressure of donor. Between 1 and 2 donor's trachea closed.

Fig. 3. 6/9/1925. Estimation of amount of epinephrin discharged. Effect of adrenal blood on blood pressure of test animals. 1. Two minutes before asphyxia. 2. During 1 st and $2 \mathrm{~d}$ minutes of asphyxia. 3. During $3 \mathrm{rd}$ and 4 th minutes. 4. During 5 th and 6 th minutes.

Fig. 4. 6/10/1925. Estimation of amount of epinephrin discharged. 1 to 8 : Effects on blood pressure of adrenal blood collected every minute after asphyxia, injected alternately into two test animals.

Fig. 5. 6/30/1925. Upper curve-Blood pressure of the recipient (29 $\mathrm{kgm}$.). Lower curve-Blood pressure of the donor $(30 \mathrm{kgm}$.). Time in minutes-30 $\mathrm{mgm}$. potassium cyanide intravenously to the donor.

Fig. 6. 8/4/1925. Time in minutes. Upper curve-Blood pressure of recipient (9.5 kgm.). Lower curve-Blood pressure of donor (15 kgm.). Between arrows donor breathed a nitrogen atmosphere with only 5.7 per cent oxygen.

Fig. 7. 8/10/1925. Time in minutes. Upper curve-Blood pressure of recipient (12 kgm.). Lower curve-Blood pressure of donor $(14 \mathrm{kgm}$.). Between the arrows the donor breathed air with 16.4 per cent CO. Rise of blood pressure in recipient when pure air is restored. 

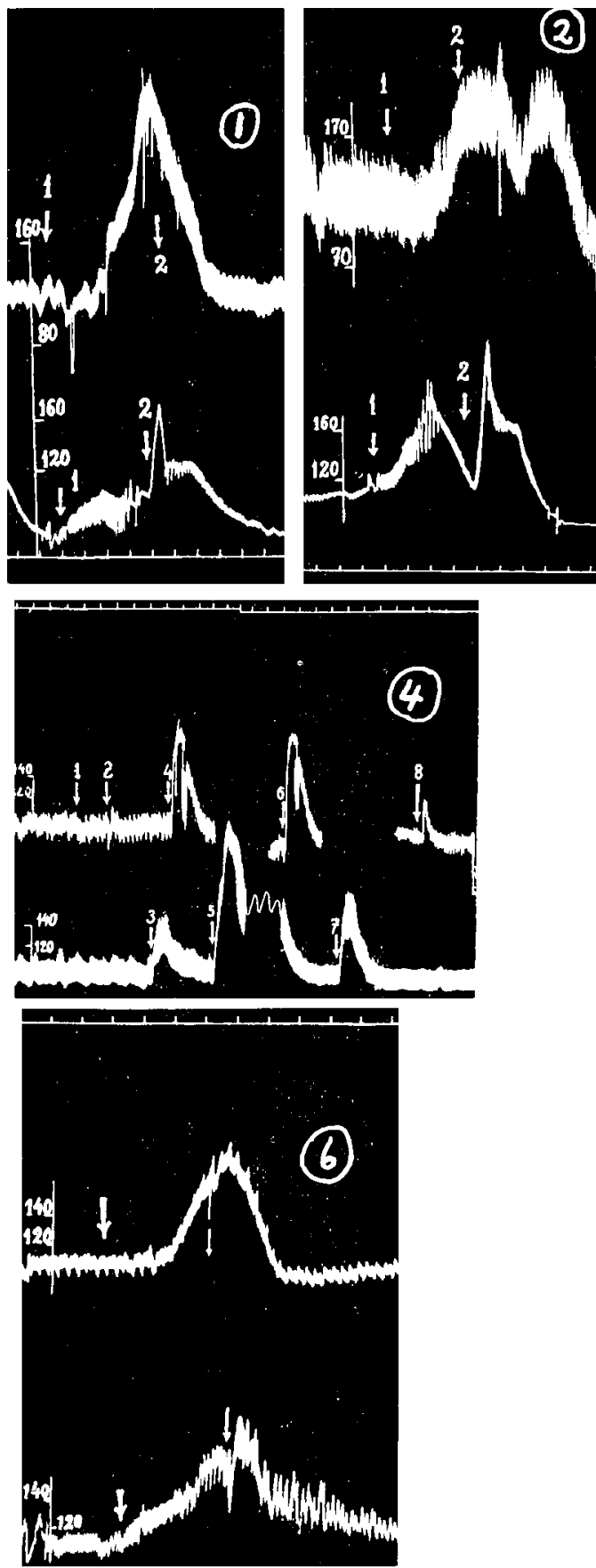
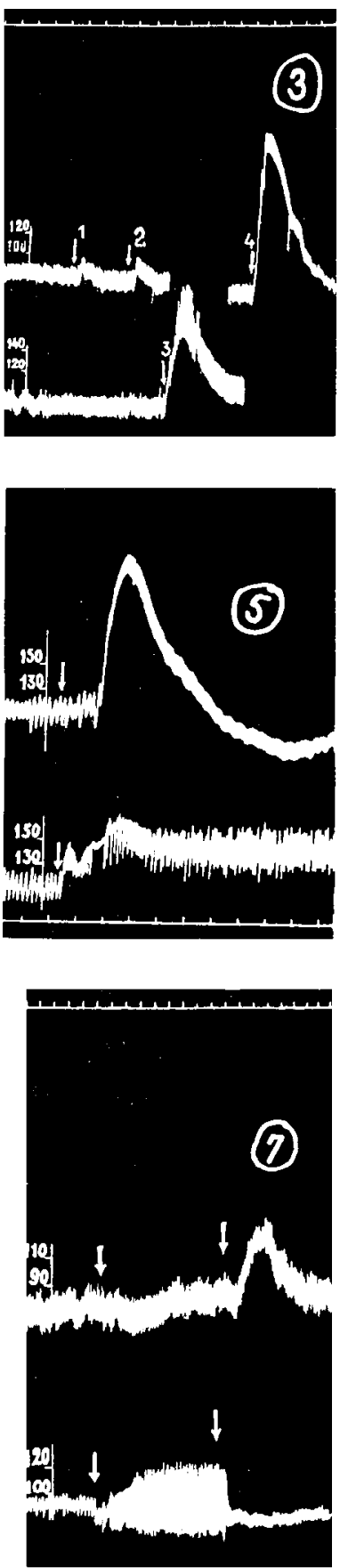
3rd experiment. Donor's weight $20.5 \mathrm{kgm}$.; left adrenal 1.55 grams. Test dogs weighed 7.5 and $8 \mathrm{kgm}$. Asphyxia lasted six minutes.

\begin{tabular}{|c|c|c|}
\hline & $\begin{array}{l}\text { BLOOD } \\
\text { COLLECTED }\end{array}$ & $\begin{array}{l}\text { EPINEPHRIN } \\
\text { CONTENT }\end{array}$ \\
\hline & $c c$ & mgm \\
\hline $\begin{array}{l}2 \text { minutes before asphyxia.................... } \\
\text { Asphyxia: Duration in minutes: }\end{array}$ & 13 & 0.0007 \\
\hline $1-2 \ldots \ldots \ldots \ldots \ldots \ldots \ldots \ldots \ldots \ldots \ldots \ldots$ & 12 & 0.0010 \\
\hline $3-4 \ldots \ldots \ldots \ldots \ldots \ldots \ldots \ldots \ldots \ldots \ldots$ & 22 & 00300 \\
\hline $5-6 \ldots \ldots \ldots \ldots \ldots \ldots \ldots \ldots \ldots \ldots \ldots \ldots$ & 11 & 0.0650 \\
\hline
\end{tabular}

As can be seen in the protocols, the maximum discharge occurs between 5 and 6 minutes after asphyxia is begun. An increased blood output is present 3 to 4 minutes after commencement of asphyxia. There is no parallelism between the quantity of epinephrin discharged and that of blood circulating through the gland.

B. Curare AND Cobra venom: Curare and cobra venom produce asphyxia by paralysis of the respiratory muscles and therefore an adrenal discharge.

Experiment of 5/27/1925. Donor's weight $17.5 \mathrm{kgm}$. Recipient's weight 9 $\mathrm{kgm}$. One milligram cobra venom intravenously injected in donor. Artificial respiration was stopped 17 minutes later, asphyxia was complete in a few minutes. Blood pressure rose $36 \mathrm{~mm}$. $\mathrm{Hg}$. The recipient showed a sharp rise of blood pressure $(90 \mathrm{~mm} . \mathrm{Hg}) 2 \frac{1}{2}$ minutes after asphyxia began and the heart rate increased 20 beats per minute. Three and a half minutes after artificial respiration was stopped it was again started, the blood pressure returned to its original level in $4 \frac{1}{2}$ minutes and the heart rate fell to normal in 4 minutes.

Experiment of $6 / 7 / 1925$. The same technique as in the experiment just recorded, but donor injected with curare instead of cobra venom. The donor's blood pressure rose $50 \mathrm{~mm}$. $\mathrm{Hg}$ during asphyxia. The recipient had a sharp rise of blood pressure $3 \frac{1}{2}$ minutes after asphyxia started and an increase in pulse rate of 32 beats per minute.

C. Potassium cyanide: A dog (donor) weighing $31 \mathrm{kgm}$. receives 30 mgm. potassium cyanide intravenously. The blood pressure of the recipient $\left(29 \mathrm{kgm}\right.$.) rose $1 \frac{1}{2}$ minute later from $120 \mathrm{~mm}$. IIg to $234 \mathrm{~mm}$. $\mathrm{Hg}$ and had an increase in heart rate of 32 beats per minute beginning 2 minutes after the injection and lasting for more than 4 minutes. The donor had only a slight rise of blood pressure, owing perhaps to a diminished sensitiveness of the vasomotor system. Evans has reported that cyanides diminish the blood-pressure response to adrenaline and splanchnic stimulation.

D. BReathing GaS MIXTURES POOR IN OXYGEN OR RICH IN $\mathrm{CO}_{2}$. Both animals were anesthetized with chloralose. The donor, whose vagi were intact, had a tracheal cannula with two valves inserted. The inspiratory valve communicated with the open air or with a rubber bag containing the 
gas mixtures studied, nitrogen and oxygen or air and $\mathrm{CO}_{2}$ mixtures (Doctor Artundo checked their composition by means of Haldane's gas-analysis apparatus). The anastomosis was performed; the recipient's blood pressure and rate of denervated heart were recorded. After a few minutes of observation during which the donor breathed room air the inspiratory valve was connected with the gas bag until the content ( 80 liters) had been used up. Table 2 summarizes the results obtained. Oxygen lack is the efficient cause of the discharge; carbon dioxide apparently plays no part.

When the mixtures were breathed during 10 minutes epinephrin was discharged with $\mathrm{O}_{2}$ concentrations of $5.7,5.9,6.3$ and 8.7 per cent. No

TABLE 2

\begin{tabular}{|c|c|c|c|c|c|c|c|c|c|c|}
\hline \multirow[b]{2}{*}{ DATE } & \multicolumn{2}{|c|}{ WEIGHT } & \multicolumn{2}{|c|}{$\begin{array}{l}\text { GAS MIXTVRE } \\
\text { BREATHED } \\
\text { BY DONOR }\end{array}$} & \multirow[b]{2}{*}{ 国 } & \multicolumn{2}{|c|}{$\begin{array}{l}\text { BLOOD } \\
\text { PRESSURE } \\
\text { RISE }\end{array}$} & \multirow{2}{*}{ 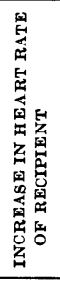 } & \multirow{2}{*}{ 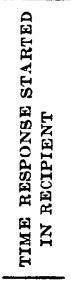 } & \multirow[b]{2}{*}{ OBSERVATIONS } \\
\hline & 蒿 & 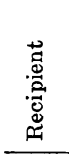 & 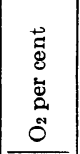 & 跑 & & 蒫 & 莺 & & & \\
\hline & $\mathrm{kgm}$. & $\mathrm{kgm}$. & & & $\begin{array}{l}\text { min- } \\
\text { utes }\end{array}$ & $\underset{H g}{m}$. & $\underset{H g}{m m}$. & & $\begin{array}{l}\text { min- } \\
\text { utes }\end{array}$ & \\
\hline $8 / 3 / 1925$ & 22 & 8 & 17 & & 8 & 0 & 0 & 0 & 0 & \\
\hline $8 / 4 / 1925$ & 15.5 & 9.5 & 15 & 64 & 10 & 0 & 0 & 0 & 0 & \\
\hline $8 / 4 / 1925$ & 15.5 & 9.5 & 11 & 40 & $4 \frac{1}{2}$ & 20 & 10 & 0 & 2 & \\
\hline $8 / 11 / 1925$ & 23 & 13 & 9.3 & 80 & 7 & 0 & 0 & 0 & 0 & \\
\hline $8 / 10 / 1925$ & 14 & 12 & 8.7 & 81 & 10 & 16 & 0 & 2 & 2 & \\
\hline $8 / 8 / 1925$ & 17.5 & 10 & 6.3 & 34 & 7 & $\begin{array}{l}10 \\
80\end{array}$ & $\begin{array}{l}10 \\
40\end{array}$ & $\begin{array}{r}2 \\
14\end{array}$ & & $\begin{array}{l}\text { Breathing gas mix- } \\
\text { ture } \\
\text { Pure air just started }\end{array}$ \\
\hline $8 / 7 / 1925$ & 17 & 9 & 5.9 & 68 & 10 & 30 & 12 & 6 & $1 \frac{3}{4}$ & \\
\hline $8 / 11 / 1925$ & 15 & 9.5 & $\begin{array}{c}5.7 \\
\mathrm{CO}_{2} \\
\text { per } \\
\text { cent }\end{array}$ & 27 & $3 \frac{1}{2}$ & c0 & 80 & 62 & 2 & \\
\hline $8 / 7 / 1925$ & 17 & 9 & 4.1 & 63 & 15 & 0 & 0 & 0 & 0 & \\
\hline $8 / 8 / 1925$ & 17.5 & 10 & 7 & 75 & 8 & 6 & 0 & 0 & 0 & \\
\hline $8 / 10 / 1925$ & 14 & 12 & 16.4 & 80 & 8 & 30 & $\begin{array}{r}0 \\
50\end{array}$ & $\begin{array}{r}0 \\
14\end{array}$ & 0 & $\begin{array}{l}\text { Breathing mixture } \\
\text { Pure air just started }\end{array}$ \\
\hline $8 / 11{ }^{\prime} 1925$ & 23 & 13 & 28 & 80 & $3 \frac{2}{3}$ & $\begin{array}{l}-30 \\
+40\end{array}$ & 0 & 4 & & \\
\hline
\end{tabular}

discharge was recorded with $\mathrm{O}_{2}$ concentration above 11 per cent. In one experiment an $\mathrm{O}_{2}$ concentration of 11 per cent produced a slight discharge. When adrenal secretion increased, the blood pressure rose in the donor and gradually rose in the recipient. One case (5.7 per cent $\mathrm{O}_{2}$ ) showed a sharp increase in the blood pressure of the recipient 2 minutes after the commencement of asphyxia. When the donor again breathed pure air the blood pressure gradually fell to the previous level in both doge. 
In one experiment ( 6.3 per cent $\mathrm{O}_{2}$ ) when the breathing of pure air was reestablished a sharp rise of blood pressure was registered in both dogs accompanied by an increased heart rate in the recipient.

Air rich in $\mathrm{CO}_{2}$ produced deep breathing and slowed the heart rate in the donor. The recipient's blood pressure never rose and, in one case (16.4 per cent $\mathrm{CO}_{2}$ ), there was a fall, followed by a rise when pure air was again given to the donor. The pulse rate was slower, 2 beats per minute with 7.7 per cent $\mathrm{CO}_{2}$ and 6 beats per minute with 16.4 per cent $\mathrm{CO}_{2}$. When 28 per cent $\mathrm{CO}_{2}$ was breathed, a rise of 2 beats per minute was followed by a fall of 2 beats.

In conclusion it can be stated that a lowered oxygen pressure increases adrenal secretion. Increased $\mathrm{CO}_{2}$ tension does not influence it to any great extent; it seems to diminish it slightly, though in one experiment (28 per

TABLE 3

\begin{tabular}{|c|c|c|c|c|c|c|c|}
\hline \multirow{2}{*}{ Date } & \multicolumn{2}{|c|}{ WEIGHT } & \multirow{2}{*}{ 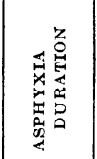 } & \multicolumn{2}{|c|}{$\begin{array}{c}\text { BLOOD } \\
\text { PRESULE } \\
\text { VARIATION }\end{array}$} & \multirow{2}{*}{ 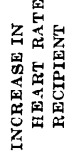 } & \multirow{2}{*}{ OPERATION PERFORMED } \\
\hline & Donor & $\begin{array}{c}\text { Recip- } \\
\text { ient }\end{array}$ & & Donor & $\begin{array}{c}\text { Recip- } \\
\text { ient }\end{array}$ & & \\
\hline & $\mathrm{kgm}$. & $\mathrm{kgm}$. & minutes & $m m . H g$ & $m m . H g$ & & \\
\hline $6 / 1 / 1925$ & 15.5 & 12.5 & 3 & 0 & 0 & 0 & Major splanchnic cut \\
\hline $6 / 1 / 1925$ & 15.5 & 12.5 & 4 & 0 & 0 & 0 & Major splanchnic cut \\
\hline $6 / 2 / 1925$ & 24 & 5 & 4 & 0 & 0 & 0 & Major splanchnic cut \\
\hline $6 / 25 / 1925$ & 19 & 11.5 & 5 & 30 & 0 & 0 & Major splanchnic cut \\
\hline $6 / 3 / 1925$ & 18 & 10 & 4 & 30 & 0 & 0 & $\begin{array}{l}\text { Major and minor splanchnic } \\
\text { cut }\end{array}$ \\
\hline $6 / 5 / 1925$ & 23 & 9.3 & 5 & 74 & 0 & 0 & $\begin{array}{l}\text { Major and minor splanchnic } \\
\text { cut }\end{array}$ \\
\hline $7 / 20 / 1925$ & 23.5 & 11 & 6 & 0 & 0 & 0 & $\begin{array}{l}\text { Spinal cord cut just below } \\
\text { medulla }\end{array}$ \\
\hline
\end{tabular}

cent $\mathrm{CO}_{2}$ ) perhaps a small increase may have been present. A study of the effect of $\mathrm{CO}_{2}$ tension with a more sensitive method might possibly give clearer results.

Rôle played by the nervous system. Our experiments confirm Tournade and Chabrol's results. Asphyxia does not produce an increased adrenal secretion when the major splanchnics are cut in the donor (two experiments). Sometimes, as Tournade and Chabrol have remarked it is necessary to cut the minor splanchnic to prevent adrenal discharge. Complete denervation of the adrenal (see previous paper on nicotin, etc.) efficiently prevents all adrenal secretion. Section of the spinal cord just below the medulla has the same effect, though Czubalski's paper seems to indicate that in some cases asphyxia may stimulate adrenal centers. (Table 3.) 
SUMMARY

1. Closure of the trachea produced a marked adrenal discharge in 2 to 5 minutes reaching the maximal point in 5 to 6 minutes. It can be as much as $0.045 \mathrm{mgm}$. per minute.

2. This discharge was registered by a recipient dog showing $a$, rise of blood pressure; $b$, increased heart rate; $c$, constriction of the denervated limb.

3. Respiratory paralysis produced by curare or cobra venom produces asphyxia and consequently adrenal discharge.

4. Potassium cyanide produces adrenal discharge.

5. Diminished oxygen tension is the efficient cause of the discharge in these cases. $\mathrm{CO}_{2}$ accumulation has no apparent effect.

6. Asphyxia acts on the central nervous system and the stimulus is transmitted through the splanchnics.

\section{BIBLIOGRAPHY}

Anrep, G. 1912. Journ. Physiol., xlv, 318.

Borberg, N. C. 1913. Skand. Arch. Physiol., xxviii, 124.

Cannon, W. B. and R. G. Hoskins. 1911. This Journal, xxix, 274.

Cannon, W. B. 1919. This Journal, 1, 399.

Cannon, W. B. and R. Carrasco-Formiguera. 1922. This Journal, Ixi, $21 \tilde{5}$.

Crile, G. W., A. F. Rowland and S. W. Wallace. 1921. This Journal, lxvi, 304.

Czubalski, F. 1913. Zentralbl. f. Physiol., xxvii, 580.

E'vans, C. L. 1919. Journ. Physiol., liii, 17.

Gasser, H. S. And W. J. Meek. 1914. This Journal, xxxiv, 48.

Gley, E. And A. Quinquaud. 1917. C. R. Soc. Biol., Ixxx, 15.

1917-1918. Journ. de Physiol. et de Pathol. gén., xvii, 807.

1921. Arch. Internat. de. Physiol., xviii, 22.

1923. Skand. Arch. f. Physiol., xliii, 316.

Hartman, F. A., H. A. McCordock and M. M. Loder. 1923. This Journal, lxiv, 1. Ilartman, F. A. And W. E. Hartman. 1923. This Journal, lxv, 623.

Itami, S. 1912. Journ. Physiol., xlv, 338.

Kahn, W. H. 1912. Pflüger's Arch., cxlvi, 578.

Kellaway, C. H. 1919a. Journ. Physiol., liii, 210.

1919b. Medical Rescarch Committee, Special Report Series, no. 37.

Kellaway, C. H. and S. G. Cowell. 1922. Journ. Physiol., lvii, 82.

Kodama, S. 1924. Tohoku Jourr. Exper. Med., v, 47.

Peariman, I. and S. Vincent. 1919. Endocrinol., iii, 121.

Searles, J. 1923. This Journal, lxvi, 408.

Starkenstein, E. 1912. Zeitschr. exper. Path. u. Therap., x, 78.

Stewart, G. N. and J. M. Rogoff. 1916a. Journ. Pharm. Exper. Therap., viii, 479.

1916b. Journ. Exper. Med., xxiv, 709.

1917a. Proc. Soc. Exper. Biol. and Med., xiv, 77.

1917b. Journ. Pharm. Exper. Therap., x, 49.

1917c. This Journal, xliv, 543.

1918. This Journal, xlvi, 90. 
1920a. This Journal, li, 366 .

1920b. This Journal, lii, 521 .

1922. This Journal, Ixii, 93.

Tournade, A., M. Chabrol and S. Taditch. 1924. C. R. Soc. Biol., xc, 414.

Tournade, A. and M. Chabrol. 1923. C. R. Soc. Biol., lxxxviii, 1180.

1924. C. R. Soc. Biol., xci, 873.

Volhakd, F. AND W. HÜLSE. 1923. Zeitschr. f. d. gesammt. exper. Med., xxxviii, 524. 